\title{
Pengaruh Praktikum Berbasis Bahan Alam melalui Model Discovery Learning terhadap Motivasi dan Hasil Belajar Kimia Peserta Didik
}

\author{
Dewi Farianti \\ Pendidikan Kimia, Universitas Negeri Makassar \\ Email: dewifarianti.df@gmail.com \\ Muhammad Danial \\ Pendidikan Kimia, Universitas Negeri Makassar \\ Email: muh_niels@yahoo.com \\ Army Aulia \\ Pendidikan Kimia, Universitas Negeri Makassar \\ Email: auliaarmy@gmail.com
}

(Diterima: 16-Desember-2019; direvisi: 17-Januari-2020; dipublikasikan: 16-Maret-2020)

\begin{abstract}
Abstrak: Penelitian ini merupakan penelitian quasi eksperiment yang bertujuan untuk mengungkapkan seberapa besar pengaruh praktikum berbasis bahan alam melalui model discovery learning terhadap motivasi dan hasil belajar peserta didik di UPT SMA Negeri 9 Maros di Kecamatan Marusu Kabupaten Maros tahun pelajaran 2018/2019. Total populasi penelitian sebanyak 143 peserta didik dengan ukuran sampel sebanyak 71 peserta didik. Teknik penentuan sampel dilakukan dengan menggunakan cluster random sampling. Pengambilan data penelitian menggunakan instrumen berupa angket dan tes. Data penelitian dianalisis menggunakan Software SPSS. Hasil penelitian menunjukkan bahwa (1) Praktikum berbasis bahan alam melalui model discovery learning memberikan pengaruh positif terhadap motivasi belajar kimia peserta didik di UPT SMA Negeri 9 Maros dengan rata-rata 67,99\%, pada kategori tinggi, (2) Praktikum berbasis bahan alam melalui model discovery learning memberikan peningkatan hasil belajar kimia peserta didik di UPT SMA Negeri 9 Maros dengan rata-rata $75,35 \%$, pada kategori tinggi, (3) Terdapat hubungan yang signifikan dan positif antara motivasi belajar dengan hasil belajar kimia peserta didik di UPT SMA Negeri 9 Maros dengan nilai analisis korelasi sebesar 0,661.
\end{abstract}

Kata kunci: Discovery Learning; Motivasi Belajar; Hasil Belajar; Larutan Asam dan Basa.

Abstract: The study is quasi experiment research, which aims at examining the extend of the influence of practicum based on natural ingredients through discovery learning model on motivation and learning outcomes in UPT SMAN 9 Maros in Marusu subdistrict in Maros distric of academic year 2018/2019. The total of research population was 143 students with the samples 71 students. Sampling determining technique employed random sampling. Data were collected by using instruments with questionnaire and test. Data were analyzed by using SPSS software. The results of the study reveal (1) the practicum based on natural ingredients through discovery learning model gave positive on chemistry learning motivation in UPT SMAN 9 Maros with the mean percentage of $67.99 \%$, which is in high category, (2) the practicum based on natural ingredients through discovery learning model gave improvement of chemistry learning outcomes in UPT SMAN 9 Maros with the mean percentage of $75.35 \%$, which is in high category. (3) there is significant and positive correlation between motivation and chemistry learning outcomes in UPT SMAN 9 Maros with correlation analysis value of 0.661 . 
Keywords: Discovery Learning; Learning Motivation; Learning Outcomes; Acid Base.

\section{PENDAHULUAN}

Undang-undang Republik Indonesia Nomor 20 tahun 2003 tentang Sistem Pendidikan Nasional menekankan pada fungsi Pendidikan Nasional dalam mengembangkan dan membentuk watak serta peradaban bangsa yang bermartabak dengan berfokus pada potensi peserta didik. Potensi peserta didik dapat dikembangkan melalui pendidikan formal (sekolah) dengan menerapkan kurikulum yang berlaku. Utamanya pada penerapan kurikulum 2013 yang kegiatan pembelajarannya diarahkan untuk memberdayakan semua potensi yang dimiliki peserta didik agar mereka dapat memiliki kompetensi yang diharapkan melalui upaya menumbuhkan serta mengembangkan pengetahuan (knowledge), keterampilan (skill), dan sikap (attitude).

Pelajaran kimia merupakan salah satu pelajaran sains yang titik beratnya adalah eksperimentasi, sehingga model pembelajaran yang digunakan, menitikberatkan peserta didik menemukan kembali atau merekonstruksi kebenaran yang harus dipelajari. Pembelajaran sains, juga menekankankan pada pemberian pengalaman langsung untuk mengembangkan kompetensi, agar peserta didik mampu mempelajari dan memahami alam sekitar secara ilmiah.

Pembelajaran kimia sepanjang pengetahuan dan berdasarkan pengalaman peneliti, menunjukkan bahwa hasil belajar kimia di sekolah masih berada pada posisi yang belum menggembirakan. Masih banyak peserta didik yang kesulitan memahami materi kimia yang diajarkan, apalagi kalau dikaitkan dengan kegiatan pembelajaran yang dilakukan di laboratorium sekolah. Hal ini disebabkan pembelajaran dengan melibatkan kegiatan praktikum jarang dilakukan karena berbagai faktor keterbatasan yang berkaitan dengan laboratorium, keterbatasan waktu guru, penuntun praktikum, kelengkapan sarana dan prasarana. Hasil pantauan BSNP tahun 2010 terhadap delapan Standar Nasional
Pendidikan menunjukkan, bahwa masih banyak sekolah yang dalam pembelajaran tidak menggunakan laboratorium sebagai bagian dari proses pembelajaran. Salah satu faktor penyebabnya, karena sebagian besar guru belum memiliki kompetensi tentang pengelolaan laboratorium. Selain itu belum efektifnya penanaman konsep dalam proses belajar mengajar, cara penyampaian informasi, model pembelajaran serta metode pembelajaran yang didukung oleh desain pembelajaran yang belum memberikan efek nyata pada hasil belajar, juga ketersediaan sarana dan prasarana sekolah serta pendanaan.

Peningkatan aktivitas pembelajaran khususnya pembelajaran kimia tidak hanya bergelut dengan teori tetapi dirangkaikan dengan pemberian praktikum agar peserta didik termotivasi dalam belajar. Seperti yang diungkapkan Baharuddin \& Wahyuni (2007), bahwa selain faktor eksternal yang mempengaruhi proses belajar juga dipengaruhi faktor internal peserta didik, terutama dalam pembelajaran yang dilakukan di sekolah melalui beberapa tahapan yaitu motivasi, konsentrasi, mengolah, menggali dan umpan balik. Hal ini dapat diperoleh melalui pelaksanaan praktikum.

Analisis situasi yang dilakukan oleh peneliti di UPT SMA Negeri 9 Maros terkait dengan hasil belajar kimia ditemukan bahwa hasil belajar kimia masih belum memuaskan. Juga berdasarkan wawancara terhadap guru-guru kimia dalam kegiatan MGMP bahwa tingkat ketuntasan serta hasil belajar peserta didik rata-rata berada pada nilai KKM yang ditetapkan yaitu 70 . Demikian pula dengan hasil wawancara dengan peserta didik bahwa banyak materi kimia yang tidak dipahami, sehingga peserta didik merasa sulit jika dipelajari secara teori tanpa mengalaminya sendiri. Padahal materi yang yang tidak dipahami tersebut berkaitan dengan kehidupan sehari-hari, sehingga peserta didik merasa pelajaran kimia termasuk mata pelajaran sulit dan 
membosankan. Selain itu pengalaman peneliti juga menunjukkan, bahwa mempelajari kimia yang cukup kompleks, harusnya melalui kegiatan pratikum untuk lebih memahami konsep kimia, karena konsep merupakan substansial untuk dapat memahami konsep-konsep lainnya dan peserta didik dapat mengingat konsep tersebut lebih lama di benaknya. Namun, kegiatan praktikum jarang dilakukan khususnya di SMA Negeri 9 Maros. Hal ini dikarenakan keterbatasan alat dan bahan yang disediakan oleh sekolah karena terhambat pendanaan yang hanya bergantung pada dana BOS, dan lokasi sekolah yang jauh dari kota, sehingga untuk membeli bahan praktikum membutuhkan waktu untuk menjangkaunya.

Rendahnya motivasi peserta didik menjadi faktor yang memberikan konstribusi terhadap kurangnya hasil belajar ini ditunjukkan oleh sikap peserta didik dalam belajar yang tidak serius dan terlihat peserta didik merasa bosan dan menganggap kurang menarik apalagi saat diinstruksikan untuk melakukan praktikum peserta didik terlihat kurang terampil dan kebingungan. Padahal Motivasi inilah yang menjadi faktor utama dalam mempengaruhi keefektifan pembelajaran. Kegiatan belajar yang efektif mendorong peserta didik termotivasi untuk memahami materi yang diberikan, apalagi peserta didik dilibatkan untuk melakukan praktikum dan mengenal alam sekitarnya.

Salah satu model pembelajaran dengan pendekatan konstruktivisme adalah discovery learning. Model pembelajaran ini bertujuan agar peserta didik menemukan konsep dengan panduan guru sebagai fasilitator dan pertanyaan-pertanyaan melalui kegiatan praktikum dalam aktivitas pembelajaran yang mampu membangkitkan rasa ingin tahu peserta didik agar dapat mengkonstruksi kemampuan berpikirnya dalam pemecahan masalah sehingga lebih memahami materi yang disajikan dan proses pembelajaran lebih bermakna. Discovery learning memiliki tahapan dalam pembelajaran meliputi pemberian rangsangan (stimulation), identifikasi masalah (problem statement), mengumpulkan data (data collecting), mengolah data (data processing), menguji hasil (verification), dan menyimpulkan (generalization). Tahapan ini yang akan diterapkan pada kegiatan pemberian praktikum agar dapat meningkatkan motivasi belajar dan hasil belajar peserta didik sebagai upaya peningkatan kualitas dan kuantitas pembelajaran.

Penerapan model pembelajaran discovery learning melalui pemberian praktikum berbasis bahan alam digunakan dengan tujuan agar peserta didik lebih memahami materi dibandingkan hanya berteori. Melalui praktikum peserta didik lebih termotivasi dan berpikir kreatif untuk mengembangkan potensi yang dimilikinya. Melakukan pembelajaran dengan kegiatan praktikum tidak bergantung lagi pada kondisi sarana dan prasarana sekolah yang harus memadai ditambah lagi bahan-bahan kimia yang begitu mahal. Namun demikian upaya untuk tetap melakukan praktikum walaupun sarana dan prasarana kurang memotivasi peneliti untuk melakukan upaya pemberian praktikum dengan memanfaatkan lingkungan khususnya bahan di sekitar peserta didik. Pemanfaatan bahan alam selain memberikan motivasi belajar dan hasil belajar yang diharapkan juga memberikan dampak yang ramah terhadap lingkungan. Selain itu keterbatasan jarak sekolah yang jauh dari kota untuk membeli bahan kimia tidak lagi menjadi kendala sehingga pembelajaran efektif dalam menumbuhkan motivasi dan hasil belajar peserta didik di bidang ilmu kimia.

Sejalan dengan penelitian yang dilakukan oleh Bakar (2014) menunjukkan hasil bahwa motivasi dan hasil belajar siswa SMK se Sumatera Barat memiliki hubungan yang signifikan dan positif. Motivasi tinggi yang dimiliki oleh siswa dalam kegiatan praktikum sangat berperan dalam peningkatan hasil belajar siswa. Selain itu penelitian Freedman (1997) juga menunjukkan ada perbedaan secara signifikan prestasi belajar siswa yang rutin melakukan kegiatan praktikum dengan siswa 
yang tidak memiliki pengalaman praktikum. Menurut Poedjiadi (2005), dalam topik pembelajaran dengan kehidupan sehari-hari dalam masyarakat, dapat meningkatkan motivasi dan hasil belajar peserta didik. Oleh karena itu salah satu yang mampu membangkitkan motivasi belajar peserta didik dalam aktivitas pembelajaran dengan melakukan kegiatan praktikum sebagai upaya pencapaian tujuan pembelajaran.

Materi kimia yang erat kaitannya dengan kehidupan sehari-hari salah satunya adalah larutan asam basa. Sebagai contoh penggunaan cuka, obat maag ataupun sabun mandi merupakan zat yang tergolong dalam asam dan basa. Zat ini sering dipakai oleh peserta didik, sehingga mereka termotivasi untuk belajar materi ini. Pada materi larutan asam dan basa peserta didik diarahkan untuk mengidentifikasi zat yang tergolong asam atau basa, dan untuk mengetahui sifat suatu larutan asam atau basa, serta menghitung $\mathrm{pH}$ larutan asam atau basa. Ini dapat dilakukan dengan menggunakan indikator. Indikator asam basa yang biasa digunakan yaitu kertas lakmus, larutan indikator, indikator universal dan $\mathrm{pH}$ meter. Penggunaan kertas lakmus ataupun indikator universal dengan cara mencelupkan ke dalam larutan terkadang sulit dibaca karena warna akan memudar ketika kertas diangkat. Sedangkan untuk penggunaan larutan indikator harganya mahal. Begitu pula penggunaan $\mathrm{pH}$ meter belum semua sekolah memiliki $\mathrm{pH}$ meter dan jika ada tersedia di laboratorium $\mathrm{pH}$ meter, harus dinormalisasikan dalam larutan buffer, sedangkan untuk membuat larutan buffer bahannya belum tersedia. Oleh karena itu diperlukan upaya untuk menanggulangi keterbatasan ini.

Salah satu upaya yang dapat
dilakukan untuk menanggulangi
keterbatasan di atas adalah penggunaan
indikator alami sebagai alternative
penggunaan indikator sintetik. Berdasarkan
hal ini peneliti mengangkat judul Pengaruh
Praktikum Berbasis Bahan Alam Melalui
Model Discovery Learning terhadap
Motivasi dan Hasil Belajar Kimia Peserta
Didik Pada UPT SMA Negeri 9 Maros.

\section{METODE}

$\begin{array}{ccr}\text { Penelitian } & \text { ini } & \text { berdasarkan } \\ \text { pendekatannya } & \text { merupakan } & \text { penelitian }\end{array}$ kuantitatif dengan metode eksperimental. Penelitian dilaksanakan dalam suasana kelas normal tanpa merubah komposisi kelas yang sudah ada. Penelitian ini merupakan penelitian eksperimen semu (quasi experiment). Desain pada penelitian ini antara variabel bebas (X) dan variabel terikat $\left(\mathrm{Y}_{1}\right.$ dan $\left.\mathrm{Y}_{2}\right)$.

Variabel dalam penelitian ini meliputi variabel independent (bebas) yaitu pemberian praktikum berbasis bahan alam melalui model discovery learning (X), sedangkan variabel terikat yaitu motivasi belajar $\left(\mathrm{Y}_{1}\right)$ dan hasil belajar kimia $\left(\mathrm{Y}_{2}\right)$ peserta didik kelas XI di UPT SMA Negeri 9 Maros pada materi larutan asam dan basa.

Proses pengumpulan data pada penelitian ini menggunakan instrumen tes dan instrumen nontes. Teknik analisis data yang digunakan dalam penelitian ini adalah teknik analisis statistik deskriptif dan teknik analisis statistik inferensial. Data yang diperoleh dianalisis secara dekriptif dengan tujuan untuk menggambarkan objek yang diteliti. Deskripsi data dari variabel penelitian dilakukan dari data sampel yang diperoleh. Deskripsi yang dimaksud adalah distribusi frekuensi, mean, median, modus, range, kategori dan persentase dari setiap variabel. Sedangkan statistik inferensial merupakan analisis data dengan melakukan pengujian terhadap hipotesis penelitian yang diajukan oleh peneliti dan dibangun dari kajian teori. Sebelum dilakukan uji statistik inferensial, terlebih dahulu perlu dilakukan uji asumsi atau uji prasyarat analisis.

Uji prasyarat analisis dilakukan untuk menentukan jenis statistik yang digunakan. Statistik parametrik memerlukan data berdistribusi normal dan homogen. Uji normalitas data menggunakan uji normalitas Kolmogrov-Smirnov. Sedangkan uji homogenitas bertujuan untuk mengetahui apakah data yang diperoleh homogen atau tidak. Uji homogenitas ini menggunakan bantuan program komputer program SPSS 17 for windows pada taraf signifikan 5\%. 
Analisis yang digunakan untuk uji hipotesis penelitian yaitu uji beda atau uji $\mathrm{T}$. Uji T yang digunakan yaitu Uji Independent Sample T-Test. Uji Independent Sample TTest adalah metode yang digunakan untuk membandingkan dua kelompok rata-rata dari dua sampel yang berbeda (independent). Pada prinsipnya uji Independent Sample TTest berfungsi untuk mengetahui apakah ada perbedaan rata-rata antara dua populasi dengan membandingkan dua rata-rata sampel.

\section{HASIL DAN PEMBAHASAN}

Pengumpulan data untuk variabel pelaksanaan praktikum melalui pemberian angket kepada peserta didik pada kelas eksperimen. Angket ini berisi pernyataan tentang keterlaksanaan praktikum yang dilakukan oleh peserta didik. Sebelum digunakan angket ini divalidasi oleh tim ahli validator, ini dilakukan untuk mengetahui tingkat keterbacaan dari tiap butir angket sebagai alat pengumpul data yang valid.

Hasil data perhitungan angket pelaksanaan praktikum berbasis bahan alam pada kelas eksperimen dapat dilihat pada Tabel 1.

Tabel 1. Statistik Deskriptif Keterlaksanaan Praktikum Berbasis Bahan Alam

\begin{tabular}{cc}
\hline Statistik Deskriptif & Nilai Statistik \\
\hline N (ukuran sampel) & 35 \\
Mean (rata-rata) & 91,33 \\
Median (nilai tengah) & 91,07 \\
Range & 18 \\
Nilai Maksimum & 98,21 \\
Nilai Minimum & 78,57 \\
\hline Jumlah & 1790 \\
\hline
\end{tabular}

Data hasil perhitungan angket pelaksanaan praktikum berbasis bahan alam kemudian dikelompokkan dalam empat kategori berdasarkan persentasenya. Data ini dapat dilihat pada Tabel 2 .

Tabel 2. Kategori Skor Angket Pelaksanaan Praktikum Berbasis Bahan Alam

\begin{tabular}{cccc}
\hline Interval Penilaian $(\%)$ & Jumlah & Persentase & Keterangan \\
\hline $80-100$ & 22 & 62,86 & Sangat Tinggi \\
$60-79$ & 12 & 34,29 & Tinggi \\
$40-59$ & 1 & 2,85 & Cukup \\
$20-39$ & 0 & 0 & Rendah \\
$0-20$ & 0 & 0 & Sangat Rendah \\
\hline Jumlah & 35 & 100 & \\
\hline
\end{tabular}

Berdasarkan perhitungan angket dari peserta didik maka pada tabel 2 di atas dapat diketahui bahwa tingkat pelaksanaan praktikum berbasis bahan alam berada pada kategori sangat tinggi sebesar $62,86 \%$, kemudian pada kategori tinggi sebesar $34,29 \%$, pada kategori cukup sebesar 2,85\% dan $0 \%$ untuk kategori rendah dan sangat rendah. Dari data ini dapat disimpulkan bahwa pelaksanaan praktikum berbasis bahan alam kajian materi asam dan basa pada peserta didik kelas XI MIPA 1 di UPT SMA Negeri 9 Maros terlaksana sebagian besar.

Proses pengumpulan data untuk variabel motivasi belajar dilakukan dengan memberikan angket kepada peserta didik. Angket ini berisi tentang pernyataanpernyataan yang sesuai dengan indikator motivasi belajar setelah melalui pembelajaran kimia. Angket ini terlebih dahulu divalidasi oleh tim ahli sehingga 
dapat diuji cobakan kepada peserta didik setelah dinyatakan valid digunakan sebagai alat pengumpul data. Hasil perhitungan data angket dari motivasi belajar peserta didik di UPT SMA Negeri 9 Maros dapat dilihat pada Tabel 3.

Tabel 3. Statistik Deskriptif Motivasi Belajar Peserta Didik

\begin{tabular}{lcc}
\hline \multirow{2}{*}{ Statistik Deskriptif } & \multicolumn{2}{c}{ Nilai Statistik } \\
\cline { 2 - 3 } & Kelas Eksperimen & Kelas Kontrol \\
\hline N (ukuran sampel) & 35 & 36 \\
Mean (rata-rata) & 68,1489 & 59,0125 \\
Median & 67,4100 & 58,5200 \\
Modus (nilai yang sering muncul) & 69,63 & 56,30 \\
Standar Deviasi & 3,90698 & 3,61982 \\
Varians & 15,264 & 13,103 \\
Range (rentang skor) & 18,52 & 15,56 \\
Skor Minimum & 60,74 & 53,33 \\
Skor Maksimum & 79,26 & 68,89 \\
\hline \multicolumn{1}{c}{ Jumlah Skor } & 2385,21 & 2124,45 \\
\hline
\end{tabular}

Data hasil perhitungan angket motivasi belajar kemudian dibuatkan distribusi frekuensi berdasarkan kategorinya. Data ini dapat dilihat pada Tabel 4.

Tabel 4. Distribusi Frekuensi Kategori Motivasi Belajar

\begin{tabular}{|c|c|c|c|c|}
\hline \multirow{3}{*}{ Kriteria } & \multicolumn{4}{|c|}{ Kelas } \\
\hline & \multicolumn{2}{|c|}{ Eksperimen } & \multicolumn{2}{|c|}{ Kontrol } \\
\hline & $\mathbf{F}$ & $\mathbf{P}(\%)$ & $\mathbf{F}$ & $\mathbf{P}(\%)$ \\
\hline Sangat Tinggi & 0 & $0 \%$ & 0 & $0 \%$ \\
\hline Tinggi & 29 & $82,86 \%$ & 2 & $5,6 \%$ \\
\hline Sedang & 6 & $17,14 \%$ & 31 & $86,1 \%$ \\
\hline Rendah & 0 & $0 \%$ & 3 & $8,3 \%$ \\
\hline Sangat Rendah & 0 & $0 \%$ & 0 & $0 \%$ \\
\hline Jumlah & & $100 \%$ & & $100 \%$ \\
\hline
\end{tabular}

Berdasarkan tabel 4 dilihat bahwa sebagian besar peserta didik pada kelas eksperimen memiliki motivasi yang tinggi dengan angka persentase $82.86 \%$, motivasi sedang pada angka persentase $17.14 \%$, motivasi sangat tinggi, dan motivasi rendah berada pada persentase $0 \%$. Sedangkan untuk kelas kontrol berada pada motivasi tinggi sebesar 5,6\%, motivasi sedang $86,1 \%$, motivasi rendah sebesar $8,3 \%$. Data tersebut jika disajikan dalam bentuk diagram batang pada Gambar 1.

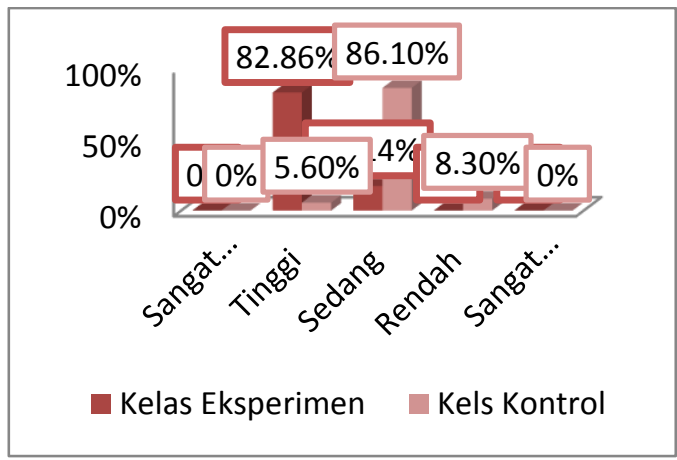


Gambar 1. Persentase Motivasi Belajar pada Kelas Eksperimen dan Kelas Kontrol

Hasil gambar 1 menunjukkan bahwa motivasi belajar peserta didik pada kelas eksperimen yang dibelajarkan dengan menggunakan model discovery learning dengan pemberian kegiatan praktikum berbasis bahan alam lebih tinggi daripada kelas kontrol yang menggunakan pembelajaran melalui model discovery learning tanpa diberikan praktikum berbasis bahan alam.

Proses pengumpulan data untuk variabel hasil belajar dilakukan dengan memberikan tes hasil belajar kepada peserta didik. Tes hasil belajar ini berisi tentang soal-soal yang sesuai dengan indikator hasil belajar setelah melalui pembelajaran kimia. Tes hasil belajar ini terlebih dahulu divalidasi oleh tim ahli sehingga dapat gunakan untuk mengukur kemampuan pengetahuan peserta didik setelah dinyatakan valid untuk digunakan sebagai alat pengumpul data. Hasil perhitungan data tes hasil belajar peserta didik di UPT SMA Negeri 9 Maros dapat dilihat pada Tabel 5.

Tabel 5. Statistik Deskriptif Hasil Belajar Peserta Didik

\begin{tabular}{lcc}
\hline \multirow{2}{*}{ Statistik Deskriptif } & \multicolumn{2}{c}{ Kelas } \\
\cline { 2 - 3 } & Eksperimen & Kontrol \\
\hline N (ukuran sampel) & 35 & 36 \\
Mean (rata-rata) & 74,00 & 51,94 \\
Median & 75,00 & 50,00 \\
Modus (nilai yang sering muncul) & 70,00 & 50,00 \\
Standar Deviasi & 8,12 & 9,43 \\
Varians & 65,88 & 88,97 \\
Range (rentang skor) & 30,00 & 40,00 \\
Skor Minimum & 60,00 & 30,00 \\
Skor Maksimum & 90,00 & 70,00 \\
\hline \multicolumn{1}{c}{ Jumlah } & 2590,00 & 1870,00 \\
\hline
\end{tabular}

Data hasil perhitungan tes hasil belajar kemudian dibuatkan distribusi frekuensi berdasarkan kategorinya. Data ini dapat dilihat pada Tabel 6.

Tabel 6. Distribusi Frekuensi Kategori Hasil Belajar

\begin{tabular}{|c|c|c|c|c|}
\hline \multirow{3}{*}{ Kriteria } & \multicolumn{4}{|c|}{ Kelas } \\
\hline & \multicolumn{2}{|c|}{ Eksperimen } & \multicolumn{2}{|c|}{ Kontrol } \\
\hline & $\mathbf{F}$ & $\mathbf{P}(\%)$ & $\mathbf{F}$ & $\mathbf{P}(\%)$ \\
\hline Sangat Tinggi & 6 & $17,14 \%$ & 0 & $0 \%$ \\
\hline Tinggi & 26 & $74,28 \%$ & 5 & $13,88 \%$ \\
\hline Sedang & 3 & $8,57 \%$ & 26 & $72,22 \%$ \\
\hline Rendah & 0 & $0 \%$ & 5 & $13,88 \%$ \\
\hline Sangat Rendah & 0 & $0 \%$ & 0 & $0 \%$ \\
\hline Jumlah & & $100 \%$ & & $100 \%$ \\
\hline
\end{tabular}

Berdasarkan tabel 6 dapat dilihat bahwa sebagian besar peserta didik pada kelas eksperimen memiliki hasil belajar sangat tinggi dengan angka persentase $17,14 \%$, hasil belajar tinggi pada angka persentase $74,28 \%$, hasil belajar sedang dengan persentase $8,57 \%$, hasil belajar rendah, dan sangat rendah berada pada persentase $0 \%$. Sedangkan untuk kelas kontrol berada pada hasil belajar tinggi sebesar 13,88\%, hasil belajar sedang $72,22 \%$, hasil belajar rendah sebesar $13,88 \%$ 
dan hasil belajar sangat tinggi, dan hasil belajar sangat rendah berada pada $0 \%$. Data

tersebut jika disajikan dalam bentuk diagram batang pada Gambar 2.

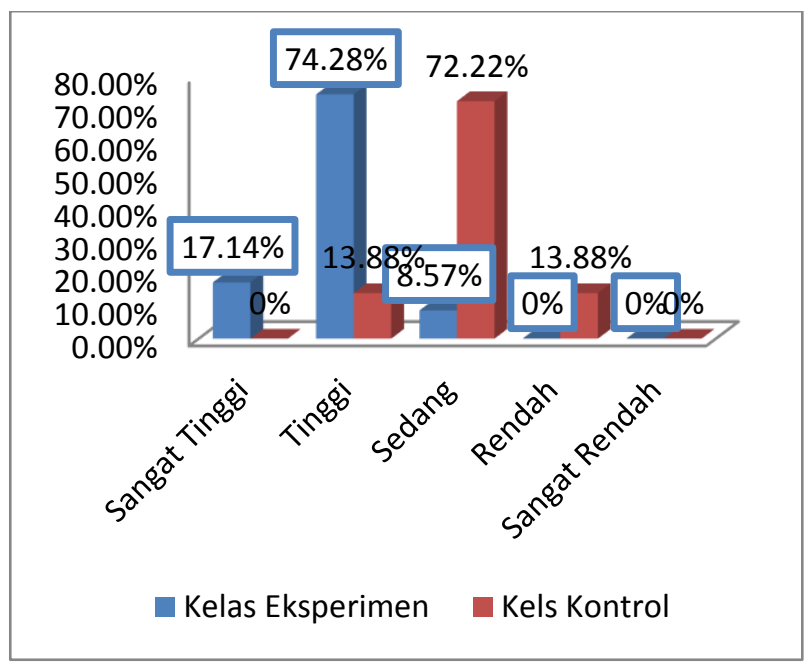

Gambar 2. Persentase Hasil Belajar pada Kelas Eksperimen dan Kelas Kontrol

Gambar di atas menunjukkan bahwa hasil belajar peserta didik pada kelas eksperimen yang dibelajarkan melalui model discovery learning dengan pemberian kegiatan praktikum berbasis bahan alam lebih tinggi daripada kelas kontrol yang menggunakan pembelajaran melalui model discovery learning tanpa pemberian kegiatan praktikum berbasis bahan alam.

Analisis statistik inferensial digunakan untuk menganalisis data dengan melakukan pengujian terhadap hipotesis penelitian yang diajukan oleh peneliti dan dibangun dari kajian teori. Sebelum analisis ini maka terlebih dahulu dilakukan uji prasyarat analisis dengan menggunakan uji normalitas dan uji homogenitas.
Uji analisis prasyarat dilakukan untuk menentukan jenis statistik yang akan digunakan. Analisis selanjutnya yang dimaksudkan adalah analisis parametrik dan analisis nonparametrik. Analisis parametrik yang digunakan memerlukan data berdistribusi normal dan homogen. Jika berbagai asumsi tersebut tidak terpenuhi maka uji analisis yang digunakan adalah analisis nonparametrik. Uji normalitas digunakan untuk mengetahui data yang diperoleh berdistribusi normal atau tidak. Pada penelitian ini menggunakan SPSS 17 for windows dengan kriteria pengujian diambil berdasarkan $\mathrm{D}_{\text {hitung }}$ dan $\mathrm{D}_{\text {tabel }}$. Adapun hasil analisisnya dapat dilihat pada Tabel 7.

Tabel 7. Hasil Uji Normalitas

\begin{tabular}{lcccc}
\hline \multirow{2}{*}{ Data } & \multicolumn{2}{c}{ Kelas Eksperimen } & \multicolumn{2}{c}{ Kelas Kontrol } \\
\cline { 2 - 5 } & Nilai Sig. & Kesimpulan & Nilai Sig. & Kesimpulan \\
\hline Motivasi Belajar & 0,194 & Normal & 0,124 & Normal \\
Hasil Belajar & 0,057 & Normal & 0,146 & Normal \\
\hline
\end{tabular}

Dari data tabel 7 dapat disimpulkan bahwa kelas eksprimen dan kelas kontrol di atas memiliki data berdistribusi normal dimana nilai signifikan lebih besar dari 0,05 (sig. $>\alpha=0,05$ ). Uji homogenitas bertujuan untuk mengetahui apakah data yang diperoleh homogen atau tidak. Pada penelitian ini menggunakan SPSS 17 for windows dengan kriteria pengujian diambil berdasarkan perbandingan nilai probabilitas yang telah ditentukan $(\alpha=0,05)$ dengan asumsi bahwa jika nilai signifikansi lebih 
besar dari taraf probabilitas $\alpha=0,05$ (sig. $>$ a) maka data berasal dari populasi yang homogen dan jika nilai signifikansi lebih kecil dari taraf probabilitas $\alpha=0,05$ (Sig. < a) maka data berasal dari populasi yang tidak homogen. Hasil uji homogenitas dapat dilihat pada Tabel 8.

Tabel 8. Hasil Uji Homogenitas

\begin{tabular}{ccc}
\hline Data & Nilai Sig. & Hasil \\
\hline Motivasi Belajar & 0,852 & Homogen \\
Hasil Belajar & 0,368 & Homogen \\
\hline
\end{tabular}

Dari analisis uji homogenitas pada tabel 8 dapat dinyatakan bahwa kedua data memiliki variansi yang sama. Ini berdasarkan nilai signifikansi untuk motivasi belajar sebesar 0,852 lebih besar dari $\alpha=$ 0,05 , demikian pula data nilai signifikansi hasil belajar sebesar 0,368 , juga mempunyai nilai yang lebih besar dari $\alpha=0,05$. Setelah uji prasyarat terpenuhi maka selanjutnya dilakukan analisis data untuk pengujian hipotesis dengan menggunakan analisis uji tsampel independen. Hasil pengujian hipotesis terhadap motivasi belajar dapat dilihat pada Tabel 9.

Tabel 9. Hasil Uji Hipotesis terhadap Motivasi Belajar

\begin{tabular}{cccc}
\hline Data Motivasi Belajar & $\mathbf{t}$ & df & Sig. (2-tailed) \\
\hline Kelas Eksperimen & $-10,224$ & 69 & .000 \\
Kelas Kontrol & $-10,213$ & 68,253 & .000 \\
\hline
\end{tabular}

Berdasarkan tabel 9 diatas dapat dilihat bahwa nilai signifikansi untuk nilai motivasi belajar antara kelas eksperimen dan kelas kontrol sebesar 0,000 dan lebih kecil dari nilai signifikansi $\alpha=0,05$. Nilai $\mathrm{t}_{\text {hitung }}$ sebesar -10,224. Sehingga $\mathrm{H}_{1}$ diterima. Maka dari hasil analisis ini dapat dikatakan bahwa terdapat pengaruh praktikum berbasis bahan alam melalui model discovery learning terhadap motivasi belajar peserta didik di UPT SMA Negeri 9 Maros pada materi asam basa. Nilai negatif pada $t_{\text {hitung }}$ menunjukkan bahwa motivasi belajar kelas eksperimen lebih besar dibandingkan motivasi belajar pada kelas kontrol. Sedangkan hasil pengujian hipotesis terhadap hasil belajar dapat dilihat pada Tabel 10.

Tabel 10. Hasil Uji Hipotesis terhadap Hasil Belajar

\begin{tabular}{cccc}
\hline Data Hasil Belajar & $\mathbf{t}$ & df & Sig. (2-tailed) \\
\hline Kelas Eksperimen & $-10,548$ & 69 & .000 \\
Kelas Kontrol & $-10,570$ & 68,008 & .000 \\
\hline
\end{tabular}

Berdasarkan tabel 10 dapat dilihat bahwa nilai signifikansi untuk nilai hasil belajar antara kelas eksperimen dan kelas kontrol sebesar 0,000 dan lebih kecil dari nilai signifikansi $\alpha=0,05$. Nilai $t_{\text {hitung }}$ sebesar $-10,548$. Sehingga $\mathrm{H}_{1}$ diterima. Dari analisis data ini dapat dikatakan bahwa terdapat pengaruh praktikum berbasis bahan alam melalui model discovery learning terhadap hasil belajar peserta didik di UPT
SMA Negeri 9 Maros pada materi asam basa. Nilai negatif pada $t_{\text {hitung }}$ menunjukkan bahwa hasil belajar kelas eksperimen lebih besar dibandingkan hasil belajar pada kelas kontrol. Hasil pengujian hipotesis seperti yang disajikan pada tabel 11 dengan analisis regresi sederhana dapat digunakan untuk menguji hipotesis yang ada. Hasil pengujian hipotesis terhadap analisis data korelasi dapat dilihat pada Tabel 11 . 
Tabel 11. Hasil Analisis Data Korelasi

\begin{tabular}{|c|c|c|c|}
\hline \multicolumn{2}{|c|}{ Data } & Hasil Belajar & Motivasi Belajar \\
\hline \multirow[t]{3}{*}{ Hasil Belajar } & $\mathrm{N}$ & & 71 \\
\hline & Korelasi & & .661 \\
\hline & Sig. (2-tailed) & & .000 \\
\hline \multirow[t]{3}{*}{ Motivasi Belajar } & $\mathrm{N}$ & 71 & \\
\hline & Korelasi & .661 & \\
\hline & Sig. (2-tailed) & .000 & \\
\hline
\end{tabular}

Dari hasil pengujian tabel 11 dapat dilihat nilai signifikansi (sig.2-tailed) adalah 0,000 (lebih kecil dari $\alpha=0,05$ ), dan nilai koefesien korelasi sebesar 0,661 berada pada kategori kuat, sehingga dapat disimpukan bahwa $\mathrm{H}_{1}$ diterima atau terdapat hubungan positif antara hasil belajar dan motivasi belajar kimia peserta didik di UPT SMA Negeri 9 Maros pada materi larutan asam dan basa. Sedangkan data hasil analisis untuk persamaan regresinya disajikan atau dapat dilihat pada Tabel 12 .

Tabel 12. Hasil Analisis Hubungan Motivasi dengan Hasil Belajar

\begin{tabular}{ccccccc}
\hline Model & Nilai Koefisien & \multicolumn{2}{c}{ Nilai Konstanta } & \multirow{2}{*}{$\mathbf{t}_{\text {Tabel }}$} & \multirow{2}{*}{$\mathbf{t}_{\text {Hitung }}$} & \multirow{2}{*}{ Sig. } \\
Hubungan & Korelasi & $\boldsymbol{\alpha}$ & $\boldsymbol{\beta}$ & 2,711 & 7,311 & .008 \\
\hline RY1Y2 & 0,661 & 37,266 & 1,167 & 2,711 & \\
\hline
\end{tabular}

Hasil analisis pada tabel 12 diperoleh dari hasil perhitungan regresi yaitu:

$$
Y=37,266+0,661 Y_{1}
$$

Konstanta yang diperoleh sebesar 37,266, ini menunjukkan bahwa jika motivasi belajar tidak ada maka nilai hasil belajar $\left(\mathrm{Y}_{2}\right)$ menjadi 37,266. Hasil ini menggambarkan bahwa setiap kenaikan satu variabel nilai pada variabel motivasi belajar $\left(\mathrm{Y}_{1}\right)$, maka akan menyebabkan peningkatan sebesar 0,661 pada variabel hasil belajar $\left(\mathrm{Y}_{2}\right)$. Pembuktian hipotesis, bahwa terdapat hubungan positif antara motivasi belajar $\left(\mathrm{Y}_{1}\right)$ dengan hasil belajar $\left(\mathrm{Y}_{2}\right)$ dapat dilakukan dengan membandingkan nilai probabilitas $\alpha=0,05$. Kaidah keputusan dari pengujian hipotesis bahwa jika nilai probabilitas $\alpha=0,05$ lebih kecil atau sama dengan nilai probabilitas sig. ( $\alpha \leq$ Sig.), maka $\mathrm{H}_{0}$ diterima dan $\mathrm{H}_{1}$ ditolak, artinya tidak signifikan. Demikian pula sebaliknya jika nilai probabilitas $\alpha=0,05$ lebih besar dengan nilai probabilitas sig. $(\alpha>$ Sig. $)$, maka $\mathrm{H}_{0}$ ditolak dan $\mathrm{H}_{1}$ diterima, artinya signifikan.

Adapun hasil pengujian hipotesis diperoleh nilai probabilitas $\alpha=0,05$ lebih besar dengan nilai probabilitas sig. $=0,008$ atau $(\alpha>$ Sig.). Selain itu dapat juga diperoleh dari uji signifikansi korelasi yaitu dengan membandingkan nilai $t_{\text {Hitung }}$ dengan $t_{\text {Tabel. }}$ Kaidah keputusan hipotesis jika $t_{\text {Hitung }}<$ $\mathrm{t}_{\text {Tabel }}$ maka tidak signifikan, demikian pula sebaliknya, jika $t_{\text {Hitung }}>t_{\text {Tabel }}$ maka signifikan. Hasil yang diperoleh dari analisis pengujan hipotesis menunjukkan bahwa nilai $t_{\text {Hitung }}$ sebesar 7,311 lebih besar dari $t_{\text {Tabel }}$ sebesar 2,711 artinya signifikan. Dari kedua analisis hasil pengujian hipotesis menunjukkan bahwa $\mathrm{H}_{1}$ diterima dan $\mathrm{H}_{0}$ ditolak, ini berarti bahwa terdapat hubungan positif antara motivasi belajar $\left(\mathrm{Y}_{1}\right)$ dengan hasil belajar $\left(\mathrm{Y}_{2}\right)$.

1. Pengaruh Praktikum Berbasis Bahan Alam melalui Model Discovery Learning terhadap Motivasi Belajar Peserta Didik Di UPT SMAN 9 Maros

Berdasarkan hasil analisis deskripstif data pada tabel 4 terhadap indikator motivasi belajar peserta didik yang ada dalam penelitian ini menunjukkan gambaran umum bahwa motivasi belajar peserta didik pada kelas eksperimen berada pada kategori 
tinggi yaitu sebesar $82,86 \%$, dan kategori sedang sebesar $17,14 \%$. Sedangkan untuk kelas kontrol berada pada kategori sedang sebesar 86,10\%, kategori rendah sebesar $8,3 \%$, dan kategori tinggi sebesar 5,6\%. Hasil ini menggambarkan bahwa motivasi belajar peserta didik pada kelas eksperimen lebih besar dibandingkan peserta didik pada kelas kontrol, walaupun persentase yang dihasilkan masih beragam.

Perbedaan persentase ini dipengaruhi oleh motivasi belajar peserta didik. Hal ini terjadi karena adanya kebutuhan masingmasing peserta didik dalam proses pembelajaran. Peserta didik kurang bersemangat dalam proses pembelajaran, ini dilihat dari perilaku peserta didik kurang konsentrasi di kelas, kurang memperhatikan guru saat menjelaskan materi. Lebih lanjut lagi materi larutan asam dan basa salah satu materi yang sulit dipahami, sehingga guru harus menggunakan metode pembelajaran yang menarik dan dapat mengkondisikan kelas agar pembelajaran menjadi menyenangkan dan efisien.

Motivasi adalah kekuatan, daya dorong, dan keinginan yang kuat dalam diri peserta didik untuk belajar secara aktif, kreatif, efektif, inovatif dan menyenangkan dalam rangka perubahan perilaku baik aspek kognitif maupun psikomotorik, (Hanafiah \& Suhana, 2009). Sedangkan menurut Suprijono (2009) hakikat motivasi dalam belajar adalah dorongan internal dan eksternal pada peserta didik yang sedang belajar untuk mengadakan perubahan perilaku, hal ini juga sejalan dengan yang dikemukakan oleh Santrock (2008) motivasi memberikan pengaruh ke arah perubahan perilaku. Motivasi belajar muncul karena adanya faktor instrinsik dan faktor ekstrinsik.

Indikator instrinsik motivasi belajar adalah adanya hasrat dan keinginan untuk berhasil, adanya penghargaan dalam belajar, adanya keinginan yang menarik dalam belajar, sedangkan indikator ekstrinsik adanya lingkungan yang kondusif sehingga memungkinkan peserta didik dapat belajar dengan baik. Seperti indikator pengujian variabel motivasi dalam penelitian ini menunjukkan bahwa munculnya motivasi belajar dipengaruhi oleh faktor internal misalnya guru dalam pemilihan metode yang digunakan dalam pembelajaran, melibatkan peserta didik dalam pembelajaran serta faktor eksternal misalnya adanya lingkungan belajar yang kondusif sehingga memberikan kenyamanan kepada peserta didik di dalam belajar. Pemberian penghargaan juga dapat mendorong peserta didik lebih termotivasi dalam belajar sehingga harapannya dapat terpenuhi.

Selain itu munculnya motivasi belajar dalam diri peserta didik sangat dipengaruhi juga faktor internal baik itu dari peserta didik, guru dan sekolah, seperti yang disampaikan oleh Haryani \& Prasetya (2014), pada sosialisasi MGMP Kimia di kota Semarang, tentang penerapan, pemanfaatan indikator bahan alam dalam pembelajaran kimia. Ia menjelaskan bahwa untuk meningkatkan pemahaman dan implementasi dalam pembelajaran dapat dilakukan dengan pemanfaatan indikator alam dengan cara mengekstrak menjadi indikator alami sehingga dapat meningkatkan keterampilan guru dan siswa dalam melakukan praktikum. Demikian pula dalam penelitian Fitrian, Fadiawati, \& Tania (2014) tentang pengembangan prosedur praktikum berbasis green chemistry. Oleh Rusiani \& Lazulva (2017) dalam penelitiannya tentang pengembangan penuntun praktikum menggunakan indikator alami berbasis pendekatan saintifik. Dari hasil penelitian-penelitian ini menggambarkan bahwa pemberian praktikum adalah metode pembelajaran yang dapat dikembangkan apalagi berbasis bahan alam akan membangkitkan motivasi instriksik peserta didik sehingga motivasi ekstrinsik juga mendukung.

\section{Pengaruh Praktikum Berbasis Bahan Alam melalui Model Discovery Learning terhadap Hasil Belajar Peserta Didik Di UPT SMAN 9 Maros}

Berdasarkan hasil analisis deskripstif data terhadap variabel hasil belajar peserta 
didik yang ada dalam penelitian ini menunjukkan bahwa hasil belajar peserta didik pada kelas eksperimen berada pada kategori tinggi sebesar $74,28 \%$, kategori sangat tinggi sebesar $17,14 \%$, dan kategori sedang sebesar $8,57 \%$, sedangkan untuk kelas kontrol berada pada kategori sedang sebesar $72,22 \%$, kategori tinggi dan rendah sebesar $13,88 \%$. Hasil ini menggambarkan bahwa hasil belajar pada kelas eksperimen lebih besar daripada hasil belajar pada kelas kontrol.

Menurut Arikunto (2009) bahwa hasil belajar merupakan skor yang dicapai oleh peserta didik setelah mengikuti proses pembelajaran. Hasil belajar yang dimaksudkan adalah evaluasi yang digunakan sebagai pengumpul data untuk mengetahui tercapainya tujuan pembelajaran. Salah satu tujuan dari penelitian ini adalah mengetahui pengaruh pemberian praktikum berbasis bahan alam terhadap hasil belajar peserta didik di UPT SMA Negeri 9 Maros menggambarkan bahwa pemberian praktikum berbasis bahan alam memberikan pengaruh dalam peningkatan hasil belajar peserta didik. Pelaksanaan praktikum merupakan suatu hal yang penting dalam proses pembelajaran kimia seperti yang dijelaskan oleh Nuryanti (2011) praktikum sebagai suatu rangkaian kegiatan yang memberikan kesempatan kepada peserta didik untuk memperoleh keterampilan, sehingga kegiatan praktikum dapat mendukung proses perolehan pengetahuan dalam diri peserta didik. Praktikum juga memberikan kesempatan kepada peserta didik untuk menemukan teori, sehingga peserta didik dapat mengilustrasikan konsep dan prinsip ilmiah yang abstrak menjadi kongkrit. Oleh karena itu praktikum dapat menunjang pemahaman peserta didik terhadap materi pembelajaran yang berpengaruh pada hasil belajar. Hal ini menandakan bahwa pemberian praktikum berbasis bahan alam pada materi asam basa memberikan hasil belajar yang tinggi. Hal ini juga dipaparkan pada data hasil analisis indikator dengan rata-rata perolehan pada kelas eksperimen sebesar 75,35\%, dan pada kelas kontrol sebesar 59,72\%. Hasil ini juga menggambarkan bahwa terjadi peningkatan hasil belajar kimia peserta didik pada materi asam basa dengan pemberian kegiatan praktikum berbasis bahan alam.

Menurut Baharuddin \& Wahyuni (2007), seseorang dapat berhasil dalam belajar disebabkan oleh dua faktor yaitu faktor internal (yang berasal dari diri orang yang belajar) dan faktor eksternal yang berasal dari luar orang yang belajar. Ini juga didukung dari hasil penelitian oleh Fakhrurrazie, Hairida, \& Hadi (2016), tentang pengaruh pembelajaran metode praktikum terhadap hasil belajar siswa MAN Mempawah memberikan pengaruh sebesar 44,41\%. Oleh Hadi (2016) tentang pengaruh model pembelajaran discovery learning disertai LKS terhadap prestasi belajar siswa di SMAN 1 Karanganyar. Penelitian yang dilakukan oleh Syafi'I, Handayani, \& Khanafiyah (2014) yang menjelaskan bahwa penerapan Question Based Discovery Learning pada kegiatan praktikum dapat meningkatkan keterampilan proses sains.

\section{Hubungan Motivasi dengan Hasil Belajar Peserta Didik Di UPT SMA Negeri 9 Maros}

Berdasarkan pedoman interprestasi koefisien korelasi, sebesar nilai 0,661 yang diperoleh menunjukkan bahwa motivasi belajar dan hasil belajar peserta didik di UPT SMA Negeri 9 Maros mempunyai hubungan yang kuat. Untuk mengetahui hubungan ini bersifat hubungan positif atau hubungan negatif, maka dapat dilihat dari hasil persamaan $Y=37,266+1,167 X$. Persamaan ini menggambarkan adanya hubungan positif. Dilihat dari signifikansi antara kedua variabel.

Menurut Sardiman (2000) motivasi mampu mendorong mental peserta didik untuk menggerakkan dan mengarahkan perilaku manusia termasuk perilaku belajar. Di dalam motivasi belajar terdapat keinginan untuk aktif menggerakkan, menyalurkan dan mengarahkan sikap peserta didik untuk giat belajar sehingga tujuan pembelajaran yang dikehendaki dapat tercapai. Dalam penelitian yang dilakukan oleh Basdarmiah 
(2016) tentang Pengaruh Metode Demonstrasi terhadap Motivasi Belajar dan Hasil Belajar Peserta Didik di SMAN 3 Takalar memberikan pengaruh yang signifikan. Oleh Bakar (2014) juga membuktikan bahwa motivasi memberikan pengaruh terhadap hasil belajar siswa di pulau Sumatra sebesar 0,339\%. Juga oleh Taiyeb \& Mukhlisa (2015) menggambarkan bahwa motivasi belajar memberikan hubungan yang signifikan dengan hasil belajar.

Berdasarkan hasil penelitian dan teori, bahwa motivasi memegang peranan penting dalam peningkatan hasil belajar. Oleh karena itu sebaiknya guru harus meningkatkan motivasi peserta didik di dalam belajar. Guru juga harus memperhatikan faktor pendukung agar dalam peningkatan motivasi baik itu untuk motivasi instrinsik maupun peningkatan motivasi ekstrinsik. Sehingga dengan peningkatan motivasi peserta didik dapat belajar karena merasa membutuhkan dan mampu melakukan sebagai perubahan perilaku yang dimilikinya. Dengan demikian hasil belajar yang diharapkan dapat meningkat pula.

\section{SIMPULAN DAN SARAN}

Berdasarkan hasil analisis dan pembahasan hasil penelitian yang telah dilakukan, maka dapat disimpulkan bahwa keterlaksanaan praktikum berbasis bahan alam melalui model Discovery Learning di UPT SMA Negeri 9 Maros terlaksana sebahagian dengan kategori tinggi. Praktikum berbasis bahan alam melalui model Discovery Learning memberikan pengaruh positif terhadap motivasi belajar kimia peserta didik di UPT SMA Negeri 9 Maros. Praktikum berbasis bahan alam melalui model Discovery Learning memberikan peningkatan hasil belajar kimia peserta didik di UPT SMA Negeri 9 Maros.

\section{DAFTAR RUJUKAN}

Arikunto, S. 2009. Prosedur Penelitian, Suatu Pendekatan Praktek Edisi II. Jakarta: Rineka Cipta.
Baharuddin \& Wahyuni, E. N. 2007. Teori Belajar dan Pembelajaran. Jakarta: Ar Ruzz Media.

Bakar, R. 2014. The Effect Of Learning Motivation on Student's Productive Competencies in Vocational High School, West Sumatra. International Journal of Asian Social Science, 4(6), 722-732.

Basdarmiah, B. 2016. Pengaruh Metode Demonstrasi terhadap Motivasi Belajar dan Hasil Belajar Fisika Peserta Didik Kelas X SMAN 3 Takalar. Tesis. Makassar: Universitas Negeri Makassar.

Fakhrurrazie, F., Hairida, \& Hadi, L. 2016. Pengaruh Pembelajaran Metode Praktikum pada Materi Laju Reaksi terhadap Hasil Belajar Siswa MAN Mempawah. Jurnal Pendidikan dan Pembelajaran Khatulistiwa (JPPK), 5(3), 1-9.

Fitrian, S. M. S., Fadiawati, N., \& Tania, L. 2014. Pengembangan Prosedur Praktikum Pengaruh Katalis terhadap Laju Reaksi Berbasis Green Chemistry. Jurnal Pendidikan dan Pembelajaran Kimia (JPPK), 3(3), 1-13.

Freedman, M. P. 1997. Relationship Among Laboratory Instruction, Attitude Toward Science, and Achievement in Science Knowledge. Jurnal of Research in Science Teaching (JRST), 34(4), 343-357.

Hadi, K. 2016. Pengaruh Model Pembelajaran Discovery Learning Disertai Lembar Kegiatan Siswa (LKS) terhadap Prestasi Belajar Siswa pada Materi Hidrolisis Garam Kelas XI SMAN 1 Karanganyar Tahun Pelajaran 2014/2015. Jurnal Pendidikan Kimia (JPK), 5(1), 3240.

Hanafiah, N. \& Suhana, C. 2009. Konsep Strategi Pembelajaran. Bandung: PT Refika Aditama.

Haryani, S. \& Prasetya, A. T. 2014. Developing Metacognition of Teacher Candidates By 
Implementing Problem-Based Learning Within The Area of Analytical Chemistry. Journal of Science and Research, 3(6), 12231229.

Nuryanti, Y. 2011. Asesmen Pendidikan IPA. Yogyakarta: FMIPA Universitas Negeri Yogyakarta.

Poedjiadi, A. 2005. Pendidikan Sains dan Pembangunan Moral Bangsa. Bandung: Yayasan Cendrawasih.

Rusiani, A. F. \& Lazulva. 2017. Pengembangan Penuntun Praktikum Titrasi Asam Basa Menggunakan Indikator Alami Berbasis Pendekatan Saintifik. Jurnal Tadris Kimiya (JTK), 2(2), 159-168.

Santrock, J. W. 2008. Psikologi Pendidikan. Jakarta: Prenada Media Group.

Sardiman, A. M. 2000. Interaksi \& Motivasi Belajar Mengajar. Jakarta: Rajawali Pers.

Suprijono, A. 2009. Cooperative Learning: Teori dan Aplikasi PAIKEM. Yogyakarta: Pustaka Belajar.

Syafi' I, A., Handayani, L., \& Khanafiyah, S. 2014. Penerapan Qustion Based Discovery Learning pada Kegiatan Laboratorium Fisika untuk Meningkatkan Keterampilan Proses Sains. Unnes Physics Education Journal, 3(2), 10-17.

Taiyeb, A. M., \& Mukhlisa, N. 2015. Hubungan Gaya Belajar dan Motivasi Belajar dengan Hasil Belajar Biologi Siswa Kelas XI IPA SMA Negeri 1 Tanete Rilau. Jurnal Bionature, 16(1), 8-16. 